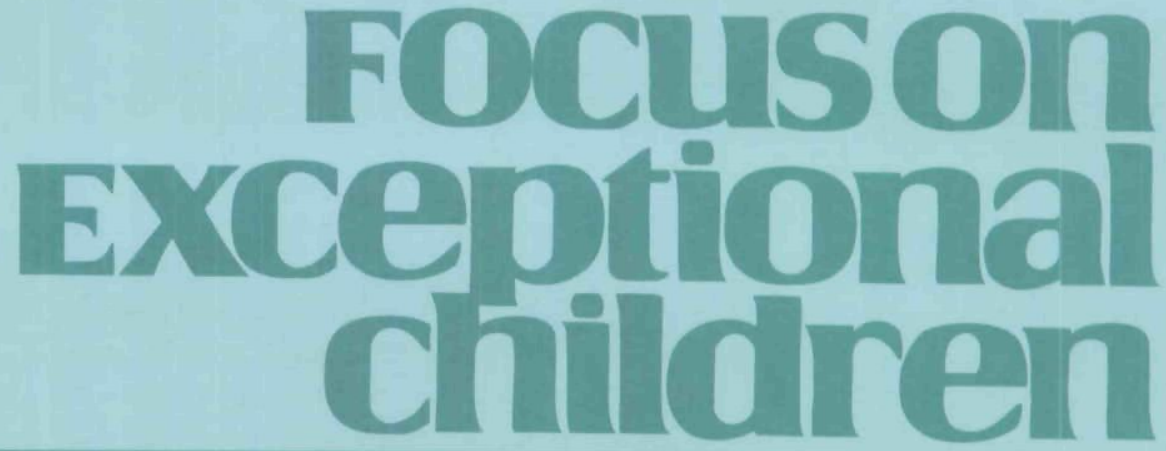

\title{
Self-Advocacy Instruction: Bridging the Research-to-Practice Gap
}

\author{
Craig R. Fiedler and Jeanne E. Danneker
}

Special education literature abounds with a challenge to special educators to promote the acquisition of self-determination skills in their students (e.g., Algozzine, Browder, Karvonen, Test, \& Wood, 2001). A critical component of self-determination that can be readily addressed in the school setting is self-advocacy. We believe that meeting the challenge of enhancing student's self-advocacy skills will require that educators understand self-advocacy and recognize its significance in obtaining successful outcomes for students with disabilities once they leave the P-12 school system. Special educators also need a clear understanding of curricula and instructional strategies that they can use to effectively promote the development of self-advocacy skills in their students (Test, Mason, Hughes, Konrad, Neale, \& Wood, 2004).

Currently, teachers face many demands to comply with school district, state, and federal mandates, which seem to be at odds with creating meaningful IEPs that meet individual student needs (Sorrentino \& Zirkel, 2004). But when teachers understand self-advocacy, recognize that it is an essential component for the success of students who have disabilities, and have the information they need to promote self-advocacy, we believe they will make time to support the development of those skills.

The many extrinsic factors that motivate teachers to address self-advocacy issues for their students include, but are not limited to, the Individuals with Disabilities Education Act (1990, 1997, 2004), the Americans with Disabilities Act (1990), the Rehabilitation Act (1973), various state statutes and regulations, national and local advocacy groups, professional literature, and conference presentations. Yet, students still do not seem to be practicing self-advocacy skills to the extent that they become self-determined adults after they complete their public education (Wehmeyer \& Schwartz, 1997). As laws and advocacy groups move beyond access to accountability, teachers recognize that special education practices must change as well.

To support teachers' understanding of why and how to make those changes, we begin with a brief discussion of self-determination theory, which points to the important role of self-determination in learning and provides context for understanding the concept of selfadvocacy. In addition, we provide definitions of self-determination and a conceptual framework for self-advocacy - the focal point of this article. We outline the need for explicit instruction related to component skills of self-advocacy and describe the barriers to providing that instruction in preschool to grade $12(\mathrm{P}-12)$ schools. Next we explore the

Dr. Fiedler is affiliated with the Department of Special Education, University of Wisconsin Oshkosh. Dr. Danneker is with the Special Education Department, Winona State University, Winona, MN. 
research-to-practice gap and offer descriptions of curricula and strategies for integrating self-advocacy skills into daily activities that we hope will bridge that gap.

Finally, we illustrate connections between theory and practice by describing the experiences of four elementary students, their parents, and their teachers as these students practiced self-advocacy by leading their own IEP meetings. Because self-determination is the broad concept of which self-advocacy is a key component, we begin with a brief overview of self-determination theory.

\section{SELF-DETERMINATION THEORY AS A MOTIVATIONAL CONSTRUCT}

Deci and Ryan (1985) defined self-determination as a psychological need based on a person's free choice. They maintain that self-determination theory (SDT) provides an explanation of the influences of intrinsic and extrinsic motivation on behavior (Deci \& Ryan, 2000). According to SDT, three innate psychological needs-autonomy, competence, and relatedness - are fundamental for healthy development

\section{Focuson
Exceptional
children}

ISSN 0015-511X FOCUS ON EXCEPTIONAL CHILDREN (USPS 203-360) is published monthly except June, July, and August as a service to teachers. special educators, curriculum specialists, administrators, and those concerned with the special education of exceptional children. This publication is annotated and indexed by the ERIC Clearinghouse on Handicapped and Gifted Children for publication in the monthly Curren Index to Journals in Education (CUE) and the quarterly index, Exceptional Children Education Resources (ECER). The full text of Focus on Exceptional Children is also available in the electronic versions of the Education Index. It is also available in microfilm from Serials Acquisitions, National Archive Publishing Company, P.O. Box 998, Ann Arbor, MI 48106-0998. Subscription rates: individual, \$42 per year; institutions, $\$ 56$ per year. Copyright @ 2007, Love Publishing Company. All rights reserved. Reproduction in whole or part without written permission is prohibited. Printed in the United States of America. Periodical postage is paid at Denver, Colorado. POSTMASTER: Send address changes to:

Love Publishing Company

Executive and Editorial Office P.O. Box 22353

Denver, Colorado 80222

Telephone (303) 221-7333

\section{EDITORIAL BOARD}
Lisa Dieker
University of Central Florida
Paula Maccini
University of Maryland
Marleen Pugach
University of Wisconsin-Milwaukee
Carrie E. Watterson Editor
Stanley F. Love Publisher

and general well-being and people are naturally motivated to take action to satisfy these needs. In addition, they argue that each of these needs is of equal importance for optimal psychological health.

Autonomy refers to opportunities to take action based on self-selected choices (i.e., volition). When teachers provide choice and acknowledge feelings, student autonomy increases (Reeve, 2006). A sense of competence results from positive feedback, indicating that students are successful because of their own efforts. Relatedness is the ability to form secure attachments to other people. When students are autonomy-oriented, they are able to develop more satisfying positive personal relationships. Satisfaction of these three needs results in increased intrinsic motivation. If these needs are not satisfied, there will be "significant negative consequences for the individual's vitality, integrity, and health" (Deci \& Ryan, 2000, p. 232).

Deficits in cognition, motivation, and emotion result when a person repeatedly experiences negative outcomes that he or she believes are beyond his or her control (Seligman, 1975). Students with disabilities often develop passive behavior as a result of being in highly structured programs where they experienced a lack of control and perceive themselves as incapable of academic success (Walker \& Bunsen, 1995). This passive behavior has been termed learned helplessness, a common attribute of students with learning disabilities and emotional disorders. While structured support from teachers is beneficial for students with disabilities, the benefit increases if the structure allows the student to experience autonomy, competence, and relatedness (Reeve, 2006).

The application of self-determination theory to educational settings has been supported by more than two decades of research. In self-determination theory, Deci and Ryan (1985) argued that development is not preprogrammed and that motivational variables provide a construct for understanding how environmental conditions affect developmental change in both positive and negative ways. They maintained that the need to be self-determined is the "primary energizer of the developmental process" (p. 116).

Many learning theories (e.g., Vygotski, Piaget, Montessori) highlight the importance of optimal challenge on the process of development. If self-determination is indeed integral to how children develop, there is no question of whether adults should foster the development of self-determination skills. If we provide structured, appropriate opportunities for students to practice these skills, we are supporting healthy psychological development. If we ignore self-determination skills, we are contributing to students' lack of psychological vitality and health. The question then becomes not how can we find time to do this but, rather, what actions can we take to support students' development of autonomy, competence, and relatedness. 
Educational definitions of self-determination provide a starting point for understanding what actions we can take to nurture self-determination component skills, especially selfadvocacy, as they develop across the life span. We will discuss definitions that have emerged as a result of increasing awareness of the essential nature of self-determination, and highlight the conceptual framework for self-advocacy developed by Test, Fowler, Wood, Brewer, and Eddy (2005).

\section{EDUCATIONAL DEFINITIONS OF SELF-DETERMINATION AND SELF-ADVOCACY}

Shortly before the reauthorization of IDEA in 1990, the U.S. Department of Education, Office of Special Education and Rehabilitative Services (OSERS) initiated several research projects to identify ways to increase self-determination skills of students with disabilities (Sands, Bassett, Lehmann, \& Spencer, 1998). Several definitions of selfdetermination resulted from the works produced through that initiative. The project directors agreed that students must identify and value their own interests and needs and have the opportunity to make choices and carry out those choices in order to become self-determined (Field, 1996).

Field, Martin, Miller, Ward, and Wehmeyer (1988) created a definition to aid in the development of curriculum and assessment of self-determination. They described self-determination as "a combination of skills, knowledge, and beliefs that enable a person to engage in goal-directed, self-regulated, autonomous behavior" (p. 2). Cross, Cooke, Wood, and Test (1999) defined self-determination as "the ability to define and achieve goals based on a foundation of knowing and valuing oneself" (p. 46).

These definitions share several common characteristics including

- the importance of self-knowledge, identifying one's own likes, dislikes, wants, needs, strengths, and limitations;

- the need for autonomy and control in decision making; and

- the significance of having opportunities to express one's needs and interests.

Many of these characteristics overlap with self-advocacy, a component skill of self-determination. The 25 definitions of self-advocacy collected by Test, Fowler, et al. (2005) included concepts such as basic human, civil, and legal rights; justice; speaking out for one's beliefs; understanding of self; independence; choice; needs; responsibilities; dignity; collaboration; and leadership. To advocate for oneself effectively, a student must recognize his or her own likes, dislikes, wants, needs, strengths, and limitations, be able to express those, and be given many opportunities to do so in authentic settings (Schreiner, 2007).
Test, Fowler, et al. (2005) developed a conceptual framework of self-advocacy to advance the development of instructional strategies and research efforts. This framework emphasized knowledge of self, knowledge of rights, communication, and leadership. Students must be aware of their own interests and preferences before they can advocate for them. Knowledge of rights empowers the student to advocate for needed services and accommodations. Communication includes several subcomponents (being assertive, negotiating, persuading, listening, etc.). Leadership may range from leading one's own IEP meeting to advocating for a group, but group leadership is not a required measure of a successful self-advocate.

\section{THE PROBLEM: LACK OF SELF-ADVOCACY INSTRUCTION}

The importance of self-advocacy training for students with disabilities during their P-12 education is rooted in legislative mandates and societal changes. Self-advocacy skills are essential for positive transitions and outcomes as students with disabilities leave the P-12 school system and enter the adult world. The Individuals with Disabilities Education Act (IDEA) amendments of 1990 and 1997 acknowledged the importance of transition services for students 16 years or older and the right of those students to participate in their own IEP meetings (Hammer, 2004; Martin, Marshall, \& Maxson, 1993; Test \& Neale, 2004; Wehmeyer \& Schalock, 2001). IDEA transition services are

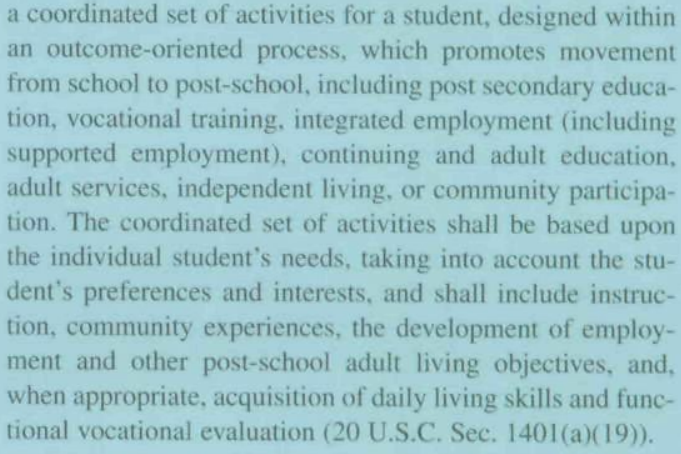

The importance of preparing students with disabilities to become self-determined adults is also the stated goal of other federal legislation. The Rehabilitation Act Amendments of 1992 and 1998 mandate that adults with disabilities be involved in the development of their individualized written rehabilitation plans (Test, Mason, et al., 2004). This renewed legislative focus on basic civil rights of individuals with disabilities to make life decisions related to educational, occupational, social, and independent living status after leaving school is reflected in the Americans with Disabilities Act (ADA) and the Section 504 antidiscrimination 
provisions of the Rehabilitation Act of 1973 (Eckes \& Ochoa, 2005; Wehmeyer, Agran, \& Hughes, 1998).

Further, significant societal changes have fueled the selfadvocacy movement. Specifically, the evolution of the normalization principle (see Wolfensberger \& Nirje, 1972), the rise of the independent living movement, the shift from institutional to community-based services, and establishment of self-advocacy groups such as People First have fostered changes in societal attitudes and treatment of individuals with disabilities (Malian \& Nevin, 2002; Miller \& Keys, 1996; Test, Fowler, et al., 2005; Traustadottir, 2006; Ward, 1994; Wehmeyer, Agran, \& Hughes, 1998).

\section{Benefits Associated With Self-Advocacy Instruction}

A number of positive benefits and post-school transitional outcomes have been associated with teaching students self-advocacy skills. Wehmeyer and Schalock (2001) maintain that individuals with self-determination skills generally have an enhanced quality of life. Indeed, self-advocacy skills are critical to the successful transition from secondary school to postsecondary education and other adult pursuits (Merchant \& Gajar, 1997; Test, Fowler, et al., 2005; Test, Karvonen, et al., 2000; Zhang, 2001).

Eisenman, Chamberlin, and McGahee-Kovac (2005) argued that students who possess self-determination knowledge and skills are more likely to have greater success in terms of employment and social interactions. Further, students who had systematic self-advocacy instruction displayed dispositional changes in terms of becoming more involved in their IEP meetings, more confident, and selfreflective about their strengths and educational needs.

Student-led IEP meetings changed the participant interaction dynamics. More positive comments were directed to the student at these meeting, and, in general, IEP team members expressed more optimism about the educational process. Students who have been trained to lead their own individualized education program (IEP) meetings are more effective at communicating their strengths, needs, goals, and, thus, in requesting appropriate accommodations from their teachers (Mason, McGahee-Kovac, \& Johnson, 2004; Torgerson, Miner, \& Shen, 2004). When students are actively involved in setting their own IEP goals, they experience a greater sense of self-efficacy and are more likely to display behaviors to attain those selfidentified goals (Wehmeyer, Palmer, Agran, Mithaug, \& Martin, 2000).

For example, in one study, three students with emotional/ behavioral disorders were taught self-advocacy by learning how to introduce their IEP meeting, review past goals, discuss future goals, and close the IEP meeting (Snyder \& Shapiro, 1997). Two of the three students demonstrated significant improvement in the self-advocacy skills they were taught, and learning these self-regulating behaviors decreased their problem behaviors.

When students are involved actively in their IEP meetings, they take more ownership of their educational experience. Quite simply, they are more motivated to work on IEP goals they helped to develop (Wehmeyer, Agran, \& Hughes, 1998). Student participation in IEP meetings personalizes the information shared and the atmosphere of the meeting. Mason, McGahee-Kovac, and Johnson (2004) studied more than 100 high school students with mild disabilities who had been provided six instructional sessions to prepare them to lead their upcoming IEP meetings. The findings revealed that the students were more involved in their own IEP meetings, knew about their disability rights and accommodations, and were more self-confident. Parental participation increased, and general education teachers participating in these student-led IEP meetings indicated that the students interacted more positively with adults and were more aware of their limitations and the resources available to them.

In a review of several self-advocacy instructional studies of students with learning disabilities transitioning from secondary to postsecondary education, Merchant and Gajar (1997) found that these students had a greater ability to name accommodations needed in college, to role-play appropriate behaviors, and to ask for help from a friend or classmate. Students with self-advocacy skills are more confident in their ability to take charge of important life decisions (Zhang, 2001).

\section{Self-Advocacy Instruction Is Not Occurring}

Given the importance of self-advocacy training, the legislative mandates, and the positive impact on post-school transition into adult life, it would be reasonable to assume that self-advocacy training of students with disabilities is a high priority and a prevalent practice in $\mathrm{P}-12$ schools. Unfortunately, the opposite is the case. Although when surveyed, teachers and administrators placed high value on self-advocacy and self-determination skills, the research indicates that students are typically unfamiliar with their IEP and are not active participants in their own IEP meetings (Snyder \& Shapiro, 1997; Test, Mason, et al., 2004).

As an example, Agran, Snow, and Swaner (1999) surveyed 100 middle school and high school special education teachers, transition specialists, job coaches, administrators, and other school personnel who serve students with mental retardation or developmental disabilities. From the 100 distributed surveys, 69 were completed and returned. When the survey respondents were asked, "How important is self-determination as a curricular area?" $42 \%$ rated it as "very important" and $35 \%$ as between medium and highest priority. Of these same respondents, $55 \%$ indicated that self-determination skills were not included in their student IEPs. Further, more than half of the respondents $(59 \%)$ stated that discussing the 
need to be self-determined with their students was not important.

In conducting a content analysis of 136 IEPs for students with mental retardation, Wehmeyer and Schwartz (1998) identified 895 transition goals in those IEPs but found no self-determination skills listed. In another study by Wehmeyer and his colleagues, only $22 \%$ of secondary-level teachers reported writing self-determination goals in IEPs for their students (Wehmeyer, Agran, \& Hughes, 2000). Lancaster, Schumaker, and Deshler (2002) cited several research studies that concluded that a majority of secondary students with disabilities had never talked to a teacher about their learning problems and that the students relied on their parents and special education teacher to advocate for them.

If students attended their own IEP meetings they rarely made positive comments about themselves or suggested goals to include in their IEPs. Although most students attend their own IEP meetings, many students are not informed about the purpose of the meeting, they are not prepared in any systematic manner for the meeting, and they do not contribute any IEP goals (Agran, Blanchard, \& Wehmeyer, 2000).

Further evidence that self-advocacy instruction is lacking in most $\mathrm{P}-12$ schools is the mounting research findings that students are leaving P-12 schools unable to function as their own advocates (Izzo, Hertzfeld, \& Aaron, 2001; Torgerson, Miner, \& Shen, 2004). As Martin, Marshall, and Maxson (1993) noted: "After exiting school, many former special education students can't plan their future, remain unemployed or underemployed, and experience a quality of life remarkably different from their nondisabled peers" (p. 53).

In a study that measured the self-determination of 80 students with cognitive and learning disabilities one year after these students left high school, Wehmeyer and Schwartz (1997) found a consistent trend that students who were provided with self-determination instruction in school were doing better (higher quality of life in terms of employment, living arrangements, and social and community inclusion) than their peers who had not been given this instruction.

A result of inadequate or nonexistent self-advocacy training is that students with disabilities face negative transitional outcomes after they leave school. A demand for educational accountability has spawned numerous studies investigating the quality and impact of special education programming on student performance upon leaving school (Katsiyannis, Zhang, Woodruff, \& Dixon, 2005; Wagner, Kutash, Duchnowski, \& Epstein, 2005; Wagner, Kutash, Duchnowski, Epstein, \& Sumi, 2005),

Two major longitudinal studies have been funded in the past several years by the U.S. Department of Education to gather data on the experiences of special education students as they transitioned from elementary schools to secondary schools and, ultimately, post-school environments. These two studies are the Special Education Elementary Longitudinal Study (SEELS) and the National Longitudinal Transition Study -2 (NLTS2). This outcomes research has been concerned with the educational, occupational, social, and independent living status of students with disabilities after leaving school. In a review of this special education outcomes research, Fiedler and Clark (2008) summarized the key findings, stating that many studies reveal that special education graduates are: (a) not employed, (b) not living on their own, (c) not integrated into their communities, and (d) not very satisfied with their lives.

Students with disabilities require explicit instruction in self-advocacy skills. The problem is the lack of an extensive research-to-practice gap in most P-12 schools. Although numerous self-advocacy and self-determination curricula are available, along with a plethora of research assessing the efficacy of self-advocacy training, students with disabilities are not learning how to advocate for themselves and, in particular, how to lead their own IEP meetings. This lack of self-advocacy instruction was captured by Martin, Marshall, Maxson, and Jerman (1993), who noted:

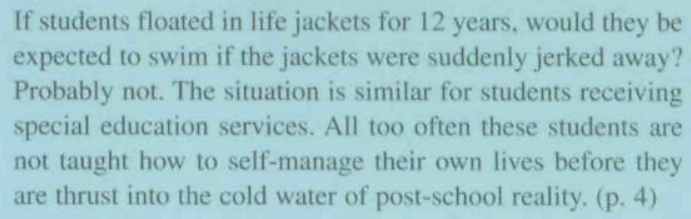

If students floated in life jackets for 12 years, would they be expected to swim if the jackets were suddenly jerked away? Probably not. The situation is similar for students receiving special education services. All too often these students are not taught how to self-manage their own lives before they are thrust into the cold water of post-school reality. (p. 4)

A number of barriers to teaching self-advocacy skills have been identified, including (Karvonen, Test, Wood, Browder, \& Algozzine, 2004):

- inadequate teacher training;

- lack of teacher initiative or authority to incorporate self-advocacy instruction into the curriculum;

- increasing accountability demands and high-stakes testing that have narrowed the curriculum and placed the educational focus on teaching traditional academic subjects;

- increasing demands on teacher time, resulting in insufficient instructional time for self-advocacy training; and

- lack of systematic commitment to a lengthy change process required to engage in new educational initiatives.

These concerns are addressed next.

\section{RESEARCH-TO-PRACTICE GAP}

As documented above, there is a substantial need for self-advocacy training for students with disabilities. Further, numerous research studies have demonstrated the efficacy of self-advocacy training in promoting more positive postsecondary and transitional outcomes for students with 
disabilities. Research further reveals that special education teachers are not devoting instructional time to teaching their students self-advocacy skills or how to lead and participate in their own IEP meetings effectively. Some of the primary reasons for this persistent divide between research findings about best educational practices and the actual instructional experiences of students with disabilities are considered in the following discussion.

\section{Traditional Special Education Instructional Model}

Historically, special education and transition programs have been predicated on an instructional model in which teachers exert full control and responsibility for making educational decisions and determining IEP goals (Agran, Blanchard, \& Wehmeyer, 2000). This perspective places students with disabilities in the passive role of recipient of decisions made by their teachers and parents. Indeed, the foundation of special education is applied behavior analysis, which promotes an instructional approach wherein the teacher implements an intervention to change a student's behavior (Alberto \& Troutman, 2006).

The teacher is the causal agent for students' behavioral change. Student compliance becomes the key behavior to other positive behaviors and learning (DiAdamo, 2005). Thus, students have learned to wait for others to decide what to do. Students with disabilities have become prompt-dependent (Agran, Snow, \& Swaner, 1999). After several years of this educational history, students with disabilities not surprisingly believe they have little control and decision-making authority over their lives. Merchant and Gajar (1997) noted:

\begin{abstract}
In many ways the educational system, from which these students have emerged, has perpetuated a false sense of dependency. For years students with disabilities have been dependent on teachers, support staff and parents to make decisions, evaluate performance and serve as their advocate. (p. 224)
\end{abstract}

Although making choices, taking risks, having control over postsecondary school outcomes, and assuming responsibility for personal actions are valued societal goals, most students with disabilities are not taught these skills and, consequently, become adults who are overly dependent on others (Mithaug, 1996).

In addition to the special education instructional perspective just described are other barriers that hinder self-advocacy instruction for students with disabilities:

1. The medical model is still prevalent within our society and schools, with the accompanying view that students with disabilities are approached from a deficit perspective and are provided with few choice-making opportunities (Abery, 1995). Individuals with disabilities must be provided with explicit instruction in making choices as an element of effective problem solving.
2. Students with disabilities are often the victims of a self-fulfilling prophecy holding that they are not capable of becoming self-advocates or leading their own IEP meetings and, thus, are not provided with those instructional opportunities (Wehmeyer, Agran, \& Hughes, 1998).

3. Accommodations are rarely in place to support students with disabilities in serving as self-advocates. For example, IEP meetings tend to be fast-paced sessions in which school personnel feel under pressure to complete the meeting in a timely manner. This self-imposed constraint is not conducive to encouraging or supporting active student participation.

4. Many educators believe that the educational planning process is too complex for students with disabilities to understand and to make reasonable and informed decisions (Wehmeyer, Agran, \& Hughes, 1998). Students with disabilities are often denied the "dignity of risk" to learn from their own decisions, whether those decisions be good or bad. They are not viewed as being agents with their own lives or as being competent to engage in self-advocacy (Grover, 2005). Some professionals even view the assertiveness associated with self-advocacy as a negative educational outcome in keeping with the student compliance roots of special education (Traustadottir, 2006).

\section{Standards-Based Educational Reform and High-Stakes Testing}

Another significant obstacle to adequate attention to selfadvocacy instruction for students with disabilities revolves around the increased demand for school accountability fueled by standards-based educational reform and highstakes testing. Beginning with IDEA 1997, states were required to include students with disabilities in district and statewide academic achievement assessments (Perner, 2007). Although this was a laudable goal in terms of establishing higher academic expectations and increasing exposure to the general education curriculum, several unintended consequences have been detrimental to the long-term educational outcomes for students with disabilities.

The No Child Left Behind Act (NCLB) of 2001, in its efforts to close the achievement gap between general education students and other educationally disadvantaged groups (e.g., students with disabilities, students from low socioeconomic groups, students of color, and students with limited English proficiency), has created several considerable challenges for educators (Sorrentino \& Zirkel, 2004). With NCLB mandates, states are required to (a) establish content standards in reading/language arts, math, and science for all students, (b) develop assessments to measure student academic performance in those content standards, and (c) define 
adequate yearly progress for each school and school district (Turnbull, Turnbull, Erwin, \& Soodak, 2006). The ultimate goal of NCLB is for every student to meet proficiency in state content standards in reading/language arts, math, and science by the end of the 2013-14 school year.

There is a basic conflict between IDEA, with its focus on the needs of individual students, and the NCLB's emphasis on school, district, and state accountability monitoring (Sorrentino \& Zirkel, 2004). With the pressure of NCLB accountability, schools will prioritize academic content that is assessed in statewide adequate yearly progress exams. Sorrentino and Zirkel speculated that "while it is not clear how this will affect students with disabilities, there is bound to be conflict between instruction designed to improve test scores and instruction separately formulated for students' IEPs" (p. 28 ). This accountability and high-stakes testing climate established by NCLB will narrow the curriculum for students with disabilities to only core academic content areas and at the same time limit the curricular attention to more functional skills such as self-advocacy instruction (Nelson, McGhee, Meno, \& Slater, 2007; Wehmeyer \& Schalock, 2001).

Thus, NCLB, with its attendant focus on access to the general education curriculum, threatens the underlying concept of individualization within the IDEA. High-stakes accountability testing, as opposed to the student's individual needs, is increasingly driving curricular and instructional decisions. In addition to narrowing the curriculum, a negative outcome of the NCLB mandates on students with disabilities is a similar narrowing of how student success is conceived and measured (Nelson, McGhee, Meno, \& Slater, 2007). That is, standardized test scores become the only valid measure of a student's performance.

Students with disabilities are assessed at their grade level, independent of their level of instruction. Therefore, as noted by Sorrentino and Zirkel (2004), a fifth-grade student in special education must take the NCLB academic content assessment at that grade level even if the student is receiving instruction at the third-grade level per the student's IEP. Students' success is limited to attaining proficiency on the state academic content standards even though the special education student may be making sufficient progress according to his or her individualized IEP goals.

When performance evaluations are not linked directly to a student's IEP goals, a serious question arises about the relevancy of the assessment process. A student's IEP should have a direct connection between assessment information and daily instruction. When the curriculum and assessment procedures are narrowed, there is no direct connection to teaching students with disabilities more functionally oriented skills such as selfadvocacy. NCLB academic content assessments contribute to teacher stress by infringing on teaching time that is relevant to students' IEP goals and instruction in functional skills.
Finally, in a review of how the NCLB has impacted education reforms in Texas, Nelson, McGhee, Meno, and Slater (2007) offered several recommendations to correct some of the unintended consequences of the law on the education of students with disabilities. In particular, two recommendations are relevant, given the concerns raised earlier.

1. Although high expectations and performance standards of all students are important, it is unrealistic to expect that all students will achieve high performance at the same time. Simply stated, not all students should be expected to show the same high degree of academic achievement, because there are undeniable differences between students that cannot be addressed by merely maintaining high expectations and accountability standards.

2. Standardized academic testing should not be the sole way to assess academic performance. Nelson et al. (2007) argue that the best indicator of learning comes when students are asked to apply their knowledge and skills in real-world situations. When provided with self-advocacy instruction, students' knowledge and skills related to actual postschool outcomes that enhance the quality of their lives become the relevant measure of student performance and success.

Self-determination skills are gained as a consequence of experiences and opportunities in multiple environments (Doll et al., 1994; Field, 1996). Limited opportunities to practice these skills as they begin to take shape result in inadequate development of self-determination (Wehmeyer, Palmer, et al., 2000). Without opportunities to apply the component skills of self-determination, students are more likely to become passive and dependent and to feel incapable of making choices and decisions (Deci \& Ryan, 2000; Field and Hoffman, 2002; Sands \& Doll, 1996). Negative consequences such as learned helplessness can result when children's needs to acquire self-determination are not satisfied (Seligman, 1975; Sutherland \& Singh, 2004).

In addition, scholars have determined that the potential for self-determination exists within all people with disabilities, regardless of their age or the severity or type of disability (Abery \& Stancliffe, 1994; Sands \& Doll, 1996). The development of self-determination skills, however, has been limited in educational practices (Agran \& Hughes, 2005). Knowing the importance of self-determination and selfadvocacy and recognizing the barriers that teachers face in their efforts to prepare their students for success beyond the classroom, we have examined resources and approaches to promote the development of self-advocacy skills and will highlight some models, curricula, and strategies that teachers can use to help their students become self-advocates. 


\section{CURRICULA AND INSTRUCTIONAL STRATEGIES FOR DEVELOPING SELF-ADVOCACY SKILLS}

Several approaches to developing self-advocacy skills are available for teachers to use, many of which require little training or expense. These include person-centered planning, selfadvocacy curricula, and a variety of instructional strategies. Additional elements essential for the successful development of self-advocacy skills involve personal, environmental, and systemic variables. Each of these will be described in turn.

\section{Person-Centered Planning}

Person-centered planning is vision-based and relies on collaboration to identify hopes, interests, needs, and goals of a person with disabilities (Keyes \& Owens-Johnson, 2003). In this method, a team, including the person with a disability, comes together to discuss issues, hopes, and dreams, to problem-solve, and to generate resources to improve the individual's quality of life. This type of planning was not designed to serve the same purpose as an IEP meeting, but the collaborative nature of person-centered planning meetings provides a useful example, and much of the information discussed can be used to address IEP issues (Blue-Banning, Turnbull, \& Pereira, 2000).

As noted earlier, demands on teachers' time preclude many nonmandated activities. Consequently, person-centered planning is not practiced widely with school-aged individuals. Nevertheless, curricular approaches for promoting self-advocacy can improve IEP meetings and foster the development of self-determination and self-advocacy skills from primary through secondary grades.

\section{Self-Advocacy Curricula}

Self-advocacy curricula tend to be directed to secondary students, but subcomponent skills should be explicitly taught at all age levels (Wehmeyer, Palmer, et al., 2000). Common skills that should be addressed include knowledge of self, knowledge of rights, perspective taking (including negotiation skills and compromise), communication skills, listening skills, and goal setting (Test, Fowler, Wood, Brewer, \& Eddy; 2005). Initially, a certain maturity level seems to be necessary to practice these skills; however, each concept should be taught in authentic settings whenever those "teachable moments" arise, regardless of the student's age. Several self-advocacy curricula will be reviewed briefly.

\section{ChoiceMaker Self-Determination Transition Curriculum}

ChoiceMaker teaches self-determination skills validated for successful transition from school to post-school settings (Martin \& Marshall, 1995). The curriculum is based on seven self-determination constructs:

1. Self-awareness

2. Self-advocacy
3. Self-efficacy

4. Decision making

5. Independent performance

6. Self-evaluation

7. Adjustment

The curriculum consists of three sections, each of which contains teaching goals, lessons, and an assessment tool.

Section One (Choosing Goals): Students learn how to articulate their personal interests, skills, limits, and goals in different self-selected transition areas such as employment, secondary education, housing and daily living, and community participation.

Section Two (Expressing Goals): Students learn the skills to manage their IEP meetings and how to publicly describe what they learned about themselves in choosing the goals lessons.

Section Three (Taking Action): Students learn how to engage in long-term planning and goal setting. Specifically, students are taught to set standards for goal performance, gather performance feedback, develop motivational strategies to accomplish their goals, employ strategies in reaching their goals, seek needed supports, and develop a schedule for goal achievement.

The ChoiceMaker curriculum was field-tested with students with behavioral and learning disabilities across several school districts (Martin \& Marshall, 1995).

\section{Whose Future Is It Anyway?}

Wehmeyer and Lawrence (1995) developed a studentdirected transition planning curriculum, Whose Future Is It Anyway?, for adolescents with cognitive and developmental disabilities. This curriculum consists of 36 sessions, in which students are taught transition planning by addressing

1. self and disability awareness,

2. decision making,

3 . identifying and accessing community resources,

4. writing and evaluating transition goals,

5. communicating effectively in small groups, and

6. developing skills to become an effective team member.

Students with adequate reading and writing skills can complete this curriculum independently; others will require support to navigate through the curricular materials. Each of the six skill areas identified above contains a variety of learning activities. Students are taught the DO IT! decision-making process:

Define the problem.

Outline your options.

Identify the outcome of each option.

Take action. Get excited! 
This curriculum was field-tested with 60 high school students with cognitive disabilities (Wehmeyer \& Lawrence, 1995). The results revealed that students felt more confident in participating in their own educational planning meetings, and students and teachers both provided positive feedback about the training process.

\section{Next S.T.E.P.: Student Transition and Educational Planning}

This transition planning curriculum consists of 16 lessons grouped into four units (Halpern et al., 1997). Lessons include teacher and student materials, videos, suggestions for family involvement, and procedures for monitoring student progress.

Unit 1 (Getting Started): Provides an overview of the transition planning process.

Unit 2 (Self-Exploration and Self-Evaluation): Focuses on student self-evaluation skills. Students are taught to identify their strengths, weaknesses, and support needs. Students complete a transition skills inventory that helps them assess their skills in four transition areas: personal life, jobs, education and training, and living independently.

Unit 3 (Developing Goals and Activities): Includes lessons on identifying goals related to the four transition areas assessed in the transition skills inventory in Unit 2.

Unit 4 (Putting a Plan Into Place): Prepares students for their transition planning meeting. This curriculum has been field-tested successfully and validated with more than 1,000 students with disabilities.

\section{TAKE CHARGE for the Future}

The Take Charge program advances adolescents' selfdetermination and transition planning through skill facilitation, mentoring, peer support, and parent support (Powers, 1996). It teaches three major skill areas for taking charge of one's future:

1. Achievement skills

2. Partnership skills

3. Coping skills

Students in this program are matched with successful adults who experienced similar challenges and share common interests. Learning activities incorporate peer support and enhance parental support through curricular materials.

\section{Self-Advocacy Strategy for Education and Transition Planning (I-PLAN)}

This self-advocacy curriculum combines student-led IEP meetings and self-advocacy instruction (Van Reusen, Bos, Schumaker, \& Deshler, 1994). Students are taught the self-advocacy instructional strategy (I- PLAN), consisting of five steps or skills:

Inventory your strengths, areas of needed improvement, and learning needs.

Provide your inventory information.

Listen and respond.

Ask questions.

Name your goals.

This curriculum has seven instructional stages:

1. Students are oriented to IEP meetings and transition planning.

2. Students are informed in greater detail about transition planning and the benefits of student participation in their own IEP meetings, and are introduced to the I-PLAN steps.

3. The teacher models the I-PLAN steps, and the students complete an individual inventory.

4. Students rehearse each step in verbal practice of the I-PLAN.

5. Students engage in group practice as they simulate an IEP meeting.

6. Students have the opportunity for individual practice and feedback with the teacher; they self-evaluate their own performance in demonstrating the I-PLAN steps.

7. Students work on generalizing the I-PLAN steps to an actual IEP meeting.

Van Reusen and his colleagues (1994) have demonstrated the efficacy of this program in enhancing student motivation and participation in IEP meetings.

\section{Instructional Strategies}

Wehmeyer, Palmer, Agran, Mithaug, and Martin (2000) developed a Self-Determined Learning Model of Instruction in which structured problem-solving discussions are used to help students acquire self-advocacy skills using developmentally appropriate activities. This instructional model consists of three phases, and each instructional phase represents a problem for students to solve by answering a series of four questions that they learn, modify, and apply to reach their self-selected goals.

\section{Phase 1: What is my goal?}

To answer this question, students respond to the following four questions:

What do I want to learn?

What do I know about it now?

What must change for me to learn what I don't know?

What can I do to make this happen?

Phase 2: What is my plan?

The four relevant questions related to this activity are:

What can I do to learn what I don't know? 
What could keep me from taking action? What can I do to remove these barriers? When will I take action?

\section{Phase 3: What have I learned?}

The corresponding set of questions for this phase are:

What actions have I taken?

What barriers have been removed?

What has changed about what I don't know?

Do I know what I want to know?

Throughout this three-phase instructional model, students are taught the essential self-advocacy skill of problem solving. Students learn how to systematically identify a problem, solutions to a problem, barriers to their problem solving, and consequences of each potential solution. The research-based instructional strategies and curricula have several instructional elements in common that have been effective in teaching self-advocacy skills to students with disabilities: explicit instruction of the necessary skills, role playing to practice newly learned self-advocacy skills, and frequent opportunities to use student self-advocacy skills. We offer a number of suggestions to provide ample learning opportunities for students to practice self-advocacy skills in daily classroom routines.

\section{STRATEGIES FOR INTEGRATING SELF-ADVOCACY INSTRUCTION INTO DAILY CLASSROOM ACTIVITIES}

As maintained in this article, the gap between research on self-advocacy instruction and the actual practice of teaching students with disabilities these skills must be narrowed or eliminated. Sometimes teachers do not see the implications of research findings for their classrooms (Test, Browder, Karvonen, Wood, \& Algozzine, 2002). Or special education teachers are overwhelmed with an ever-expanding list of roles and responsibilities (Conderman \& Katsiyannis, 2002).

For these reasons, special education teachers must be given tools and strategies to readily translate research findings into instructional practices in the most efficient and effective manner. Here we provide examples of instructional strategies that teachers can employ, incorporating self-advocacy instruction into daily classroom lessons and activities.

\section{Translating Research Findings Into Lesson Plans}

Self-advocacy instruction involves a number of teachable components, of which those discussed most frequently in the research literature include

- choice/decision making,

- goal setting,

- problem solving,
- self-evaluation/management,

- self-advocacy skills,

- planning and participating in IEP meetings, and

- self-awareness.

Test and his colleagues provide special education teachers with a tool or process for translating findings from research articles into lesson plans (Test, Browder, Karvonen, Wood, \& Algozzine, 2002). Each lesson plan includes five elements: objective, setting and materials, content taught, teaching procedures, and evaluation methods. For each lesson plan element, Test et al. discuss how to find relevant information within a research article.

For example, the objective(s) for a research article lesson plan is determined from the purpose or hypothesis of the study. Information for the lesson plan's setting and materials can usually be found within research article sections labeled as "Setting," "Materials," or "Procedures." For the content taught, the "Materials" section of a research article typically describes the instructional content of the intervention. So that research studies may be replicated, the researchers normally describe their teaching procedures in considerable detail. This information usually is found in a section labeled "Procedures," transferred readily to a lesson plan format with adequate information on how to set up the classroom instruction. Finally, for the lesson plan component on evaluation methods, a research study will describe how the "Dependent Variables" were assessed. The dependent variables represent the data collected by the researchers to determine if their intervention was effective.

Teachers should attempt to assess their students' selfadvocacy skills in role play and, ultimately, real situations in which students will be called upon to demonstrate a specific self-advocacy skill. This process provides a direct bridge between research and practice. Several examples of selfadvocacy lesson plans, curricular, and assessment materials are provided in the websites listed in Figure 1.

\section{Integrating Self-Advocacy Instruction}

Self-advocacy skills can be taught successfully within regular subject content areas, as opposed to a separate instructional activity on self-advocacy, so academic skill development is not sacrificed for functional skills instruction. As an example, Konrad, Helf, and Itoi (2007) offer practical strategies to promote both self-determination and literacy skills through the use of children's and adolescent literature. A growing list of children's literature features characters with disabilities (e.g., bibliotherapy) that have been used to enhance social skills (Cartledge \& Kiarie, 2001), self-awareness (Ford, 2000), problem solving (Harris, 1991), cognitive development (Borders \& Paisley, 1992), and self-concept (Sridhar \& Vaughn, 2000). 


\section{- http://www.uncc.edu/sdsp/self_advocacy/self advocacy.asp?FileName=project_description\&Title Banner=ProjectInformation}

This is the website of the Self-Advocacy Synthesis Project at the University of North Carolina Charlotte, a project funded in 2002 by the U.S. Department of Education, Office of Special Education Programs. It contains a multitude of useful materials, including a directory of model school programs promoting self-advocacy skills for students with disabilities, an extensive literature review of research studies on selfadvocacy, lesson plans, curricular materials, and self-advocacy-related links.

- http://web.uccs.edu/education/special/self determination/

The Center for Self-Determination at the University of Colorado at Colorado Springs is a model demonstration and outreach project funded by the U.S. Department of Education, Office of Special Education Programs. This website contains a list of self-determination curricula and materials, the ChoiceMaker Self-Determination Curriculum and lessons (available for purchase from SoprisWest.com), a bibliography on self-determination research and literature, and relevant links.

- http://www.beachcenter.org/education_and_training/ self-determination.aspx

The Beach Center on Disability at the University of Kansas is a research and dissemination institute dedicated to promoting better understanding and quality of life for individuals with disabilities and their families. One of the Center's core research missions is self-determination. This website offers a variety of self-determination instructional materials. For example, you can access books and guides to assist parents in teaching self-determination skills to their young children with disabilities. The site includes practical guides to teaching self-determination skills, curricular materials for adolescents, and current research projects. The ARC's Self-Determination Scale is available at this site, a 72 -item student self-report measure of self-determination designed for use by adolescents with cognitive disabilities. There are articles on how to promote self-determination skills and student stories about becoming self-determined.

\section{- www.Idpride.net/selfadvocacy.htm}

This website contains the LD Self-Advocacy Manual, which provides information on how to teach students about learning disabilities, their legal rights, IEPs, steps to becoming an effective advocate, and planning for the future after high school.

\section{- www.postitt.org/activities/unit01/Section1.pdf}

This website has lesson activities that teach students about their disability, how their disability affects learning, how they learn best, what accommodations they need, and how to prepare for their IEP meeting.

\section{- http://fvkasa.org}

Kids as Self Advocates (KASA), a national project of Family Voices, is a national grassroots project created by youth with disabilities. The site provides stories written by students with disabilities. In addition, it has a resources section on civil rights and advocacy, education, health, work, dating and relationships, and disability history and culture. There is a section for student poetry and art and an online discussion forum.

- www.coe.ufl.edu/Centers/TransitionCenter/ www/doc/other/Self-Determination_Models.pdf

This document provides a list of self-determination curricula.

\section{FIGURE 1 \\ Websites for Self-Advocacy}

Konrad et al. (2007) recommend a number of children's books for promoting self-determination skills, with a description of the class learning activity, the self-determination and literacy skills addressed, and accommodations/ supports for students with disabilities. A number of instructional examples for promoting the following self-determination skills of self-awareness, problem solving and decision making, goal setting and self-management, and self-advocacy are provided. These suggestions are summarized below.

\section{Self-Awareness}

- Students compare and contrast their own disabilities with the disability of a book character.

- Students compare and contrast their feelings about receiving special services with those of a book character.

- Students write present level of performance statements describing their strengths and needs compared to those of a book character.

\section{Problem Solving and Decision Making}

- Teacher discusses a conflict faced by a book character and students brainstorm possible solutions.

- Teacher fosters a discussion on how students could employ a problem-solving process to their real-life situations.

\section{Goal Setting and Self-Management}

- Teacher asks students for examples of appropriate goals for a book character based upon what students know about the character's strengths, weaknesses, and needs.

- Students discuss what self-management strategies might be helpful to a book character.

\section{Self-Advocacy}

- Students write a letter to a book character's teacher, arguing for specific accommodations or services. 
- Students role-play situations from a book in which self-advocacy skills are required.

As discussed previously, students with disabilities typically encounter curricular and instructional approaches that perpetuate their dependence on teachers who make all of the classroom decisions. This student passivity is the antithesis of self-advocacy/self-determination. Literature circles provide an opportunity for students to engage in learning activities that promote self-determination (Blum, Lipsett, \& Yocom, 2002). Literature circles are small (usually 4-6 students) temporary discussion groups composed of students who are reading the same short story, book, poem, or article.

Each student in a literature circle is assigned a different role in preparation for the discussion. Examples of student roles are discussion leader, vocabulary enricher, illustrator, connector, researcher, character captain, and conflict catcher. In this instructional activity, students take more responsibility for their own learning. As Blum et al. noted, "Self-determination is a byproduct of literature circles, and it promotes decision making, problem solving, and selfassessment" (p. 101).

Special education teachers instill self-advocacy skills by offering students choices in their assignments and instructional formats (e.g., independent seatwork, computer, peer tutoring, cooperative learning). This provides students with plenty of daily practice in choice making, problem solving, decision making, and independence. Students learn behavioral autonomy under these learning conditions. Price, Wolensky, and Mulligan (2002) offer several examples of instructional practices that enhance self-determination skills:

- Translate classroom learning to real-world settings through community-based service learning projects.

- Incorporate students' life experiences in learning activities.

- Structure teaching and learning to be more problemoriented.

- Anticipate future adult roles and responsibilities of students and incorporate that information into learning activities.

- Encourage mutual responsibility and goal setting between the teacher and students.

- Assist students in identifying their strengths and support needs.

- Promote intrinsic behavioral self-management skills as opposed to extrinsic reward systems.

- Infuse student choice throughout the school day.

\section{Use of Interactive Hypermedia}

Recognizing the challenge that special education teachers face in finding sufficient instructional time to teach selfadvocacy skills, Lancaster, Schumaker, and Deshler (2002) developed and researched the efficacy of an interactive hypermedia (IH) computer program consisting of six self-paced student lessons. Each lesson contains text with audio explanations and brief video clips of student instructors describing and modeling the self-advocacy instructional strategy. In the efficacy study of the IH computer program, 22 high school students with high-incidence disabilities were assigned randomly to one of three groups: comparison or no instruction (six students), live instruction (eight students), and interactive hypermedia (eight students). Teacher instructional time per each student in the IH group averaged about an hour. Student learning time in the $\mathrm{IH}$ group was approximately 3 hours.

Efficacy of the IH computer program was determined by assessing student knowledge of the self-advocacy instructional strategy, students' use of the strategy during an IEP meeting, number of student-generated IEP goals, student and teacher satisfaction with the IH computer program, and the required teacher instructional time. Research results demonstrated effectiveness of the $\mathrm{IH}$ computer program across all of the above dependent measures.

The six IH lessons included an Introduction, SHARE, Inventory, PLAN, Model Conferences, and Review. The SHARE lesson taught students the importance of the following IEP meeting behaviors:

Sit up straight.

Have a pleasant tone of voice.

Activate your thinking.

Relax.

Engage in eye contact.

Once students learn the SHARE behaviors, they are taught the steps and skills in the Self-Advocacy Strategy program (I-PLAN) (Van Reusen, Bos, Schumaker, \& Deshler, 1994) discussed in the previous section. Similar lessons were used to teach four elementary students to lead their IEP meetings.

\section{CASE STUDIES}

The literature reviewed for this article has noted consistently that one of the most common opportunities for students to practice their self-advocacy skills is to participate in their individualized education program (IEP) meetings. Although the occurrence of student-led IEP meetings has increased somewhat at the secondary level, secondary teachers are finding that students' lack of awareness of the purpose and importance of the IEP is a barrier to convincing the students to become involved in their meetings.

It has been suggested that students begin to participate in their IEP meetings while they are in elementary school. Following is a description of four students in grades 4,5 , and 6 who successfully led their IEP meetings. We present these case studies to illuminate some of the factors discussed thus far. We (a) identify underestimated self-advocacy skills in 
young children, (b) explain materials and training used to prepare them to lead their IEP meetings, (c) describe the self-advocacy skills used during IEP meetings, and (d) examine the challenges and lessons learned.

\section{Underestimating and Identifying Self-Advocacy Skills}

As we described earlier, a foundation of special education instruction has been the applied behavior analysis model of intervention, which tends to create dependency and learned helplessness. In addition, the medical model/ deficit perspective has led teachers and parents to believe that students who are not able to follow simple directions, hand in homework assignments on time, or exhibit positive social skills surely would have nothing to contribute to the complex IEP process. More recent research, however, has demonstrated that people with disabilities are capable of attaining some degree of self-determination and that these skills should be promoted throughout a student's development (Abery \& Stancliffe, 1994; Sands \& Doll, 1996). This examination of four elementary students and their experiences in preparing for and leading their IEP meetings illustrates the potential, procedures, and possibilities of promoting self-advocacy skills at a young age.

The four students involved in these case studies were all Caucasian - three males and one female. At the time, Kevin was 10 years old and in fourth grade, Carrie was age 11, in fifth grade. Nathan, age 13, and Nic, age 12, were in sixth grade. Each student was included as a member of his or her general education class and received pullout services in special education resource rooms. All of them had developed some self-advocacy skills prior to being trained to lead their IEP meetings, as described below.

\section{Kevin}

Kevin was referred to special education in third grade and was found to have a specific learning disability (SLD) in written language. At the time of this intervention, he was in fourth grade and usually left his classroom during language arts period to receive services from the SLD teacher in the resource room. He worked on writing fluency, spelling, and reading, even though written language was the only goal on his IEP. On some days the special education teacher worked with Kevin in the fourth-grade classroom to help him complete writing assignments from his fourth-grade teacher.

Prior to leading his IEP meeting, Kevin displayed foundational skills for self-advocacy (e.g., self-knowledge, problem solving), as described by Test, Fowler, et al. (2005). Before explicit instruction he was able to identify his own weaknesses as being problems with memory and difficulty in writing. He explained that although he wrote his assignments in his notebook, he often forgot to take the proper books home to complete assignments. He also explained that he took a long time to copy things from the board because he had to keep looking back to remind him what it said and also how to spell the words. He expressed concern about having to write long explanations in problem-solving activities.

During one of the training lessons, this fourth-grade boy was asked to make suggestions for accommodations that the general educator could use to help him learn. He said he would like the teacher to provide study guides for tests, teach test-taking skills, break down writing assignments into smaller tasks, and ask students questions about what they understand and where they need more information.

\section{Carrie}

Carrie came to her current foster home at the beginning of fifth grade. She had lived in residential treatment and foster care since the courts terminated her parents' rights when she was very young. When she first came to live with this family, Carrie was taking several medications for a number of emotional and behavior disorders. She had been diagnosed with fetal alcohol syndrome (FAS). A few other diagnoses, such as attention deficit disorder and bipolar disorder, had not been confirmed or ruled out at the time of this experience. After a few months of consistent positive behavior management, Carrie's foster mother and doctors had successfully reduced the number of medications needed to control her behavior to two medications.

The adults in this study described Carrie as having a genuinely caring nature, a good heart, and a good sense of humor. Her teachers said her reading skills were at about a first-grade level. Carrie had problems with controlling her anger and frequently used negative self-talk. Her teachers explained that she worked eagerly on tasks that she could follow easily but became easily frustrated and angry whenever academic tasks became challenging. She also stole things such as small toys from her classmates. Nevertheless, she was included in a fifth-grade general education classroom, where she participated in most class activities. Twice each day she went to the special education resource room for individualized instruction in reading and written language. She also used the resource room as needed for behavioral support. Carrie's IEP goal areas included anger management, task completion, and reading and written language skills.

Although Carrie possessed rudimentary self-advocacy skills such as being able to identify her own likes, dislikes, strengths, and weaknesses, she demonstrated an external locus of control regarding her recent skill development. She attributed her improvements to her new teacher rather than to her own efforts. In Carrie's words, "She helps me more [than the teacher I had last year]." Like Kevin, Carrie identified needs consistent with her current IEP and descriptions from her teachers and foster mother. 


\section{Nathan}

The third student to participate in his IEP meeting, 13year-old Nathan, was a sixth-grader who had been receiving special education services since kindergarten. Because his learning difficulties were attributed to physical illness, his special education label was other health impaired (OHI). He had received two liver transplants, the second only 2 years ago. After the second transplant, his health vastly improved, but because of his illness, he had missed a lot of school, resulting in gaps in his academic and social skills. All of the adults described him as being immature and too dependent on adults.

Nathan's parents and teachers described him as caring, kind, cooperative, and friendly. They said he got along well with his peers but was more of a follower than a leader in cooperative group activities. They mentioned concerns regarding his organizational skills and taking responsibility for basic things such as copying assignments from the board and putting his books into his backpack without being reminded. They all expressed a desire to see Nathan become more autonomous. The parents and teachers stated that they would like to see Nathan try to do things on his own first, then ask for help if needed. Nathan's homeroom teacher viewed him as not being academically capable of doing sixth-grade work. She stated, "It's almost impossible for him to participate, especially in social studies. It's just way over his head."

Nathan worked with the developmental disabilities (DD) teacher in the resource room for 2 hours each day, receiving individualized instruction in reading and math. The rest of the day he was included in the general education setting with other sixth graders. His general education teachers adjusted their instruction, assignments, and grading expectations for him. Nathan listed gym, reading, and math as his favorite subjects in school. He struggled with science but stated that he enjoyed that class because of his teacher. The general education teachers expressed concern that Nathan should develop more personal responsibility. His homeroom teacher said, "You just know what he's been through and you feel so bad for him you want to help him, help him, help him, but you don't want to help him to the point of being helpless."

Nic

The fourth student, Nic, was on medication for attention deficit hyperactivity disorder (ADHD) and had a learning disability in reading and written language. After his parents were divorced when he was in first grade, he had moved six times. In fifth grade he had trouble adjusting to the move, but by sixth grade he was getting along well with his peers. He liked to play football during recess, was on the wrestling team, and had an excellent memory for sports trivia. His math skills, too, were noted as one of his strengths. All of the adults interviewed mentioned that $\mathrm{Nic}$ was capable of completing sixth-grade-level work but that he struggled with organization and following through with his responsibilities. He did not complete homework assignments and turn them in on time unless his special education teacher and his stepmother checked up on him several times a day. Nic's parents and teachers wanted him to become more self-motivated. They viewed this as especially important before his going on to junior high school, where more independence would be expected.

Exhibiting self-awareness and self-evaluation, Nic identified math as his favorite subject. He said that he liked to do computation problems and that he could figure math problems related to football quickly. He revealed frequent struggles with math story problems, though. He was able to describe his daily schedule in sixth grade and said he liked doing projects in all his classes. He noted, "I wish we'd do projects every day because I've done really good on them. Tests really bomb me." From his perspective, organization was the only thing he needed to work on with his special education teachers.

\section{Materials and Student Training}

To prepare the students, training materials were created from modified curricula used with secondary students (Martin \& Marshall, 1995; Van Reusen \& Bos, 1994; McGaheeKovach, 1995) and materials developed by the Florida Department of Education (Cooper, Roder, Wichmanwoski, \& Yeretzian, 2004). The following topics were covered in the lessons:

1. Introduction to the IEP, purpose, content, and team

2. Identification of student's strengths, needs, and interests

3. Student self-evaluation of progress on current goals

4. Goal setting, and identification of helpful accommodations and modifications

5. Creation of a script to use for participation in the IEP meeting

6. Practicing for participation in the meeting

Many of the basic features of the curricula and strategies described previously were implemented, at least in part, in six 20-minute training lessons with each student. The second author worked with the students individually; however, most of these activities could be implemented with groups of students.

During the first lesson the instructor explained that IEP stands for individualized education program and that each student who works with one of the special education teachers has an IEP. Without going into detail regarding special education categorical labels, we discussed why the student was working with the special education teacher and looked at a copy of the student's current IEP. The instructor briefly described the purpose of each section of the document. The 
student was asked to make a list of those he or she thought were interested in his or her education and therefore should attend the IEP meeting.

Using that list, each student filled out an invitation for the people to be invited. The students each took responsibility for delivering the invitations to the principal, their teachers, and their parents. These students, who struggled to hand in daily homework assignments, successfully filled out and delivered every invitation in a timely manner.

In the second session we discussed subjects the student was currently studying in school. We listed the classes and put a star next to the student's favorite class and a checkmark next to the class the student said was most difficult. We discussed the student's likes, dislikes, interests, and needs. The purpose of this lesson was to have the student practice self-awareness and self-evaluation. At the end of the second session, the student and the parent were each given questionnaires to complete and return at the next session. Through the questionnaires, the parents and students identified the student's strengths and the parent's concerns and suggested goals for the new IEP. This information was used in discussions with each student in subsequent sessions as applicable.

During the third session we looked at the student's current IEP. The instructor explained what was listed in "present levels of performance" and asked the student to evaluate the accuracy of those IEP statements. We also read each goal and discussed what progress had been made and if the student thought the goal should be changed.

This discussion was continued during session four. In that session we discussed what the student thought he or she needed to do to be more successful in school. The instructor asked the students to suggest additions and changes to their goals, explained the concept of accommodations and modifications, and asked the students what kinds of things their teachers did that helped them achieve their goals.

During the fifth session the instructor and student discussed the format of an IEP meeting. The instructor explained each part of the meeting and asked the students what they might say related to that topic, then wrote the student's response in his or her exact words. These notes were used to type a script for the student to use at the IEP meeting. The script was given to the student to practice before the last training session.

The sixth session was spent reading the script and practicing for the meeting by having each student predict what comments the IEP team members would make at various points throughout the meetings. It was important that the student make good predictions so he or she would not be surprised or embarrassed by issues that might be brought up.

\section{Self-Advocacy Skills in Action}

Throughout these student-led IEP meetings the four elementary students each exhibited several component skills of self-advocacy including self-awareness, self-evaluation, problem solving, listening, and goal setting. A few days prior to each IEP meeting, the instructor shared the meeting agenda and the student's script with the special education teacher to allow her to check for accuracy in the order of the agenda and contents of the script. Also, prior to each meeting the special educators were told that they could fill in information or encourage the student as needed throughout the meeting.

Each of the four student-led IEP meetings began in a comfortable, relaxed atmosphere. The students were excited and anxious, as evidenced in follow-up interviews with parents, general education teachers, and the students themselves. Kevin's teacher described his anticipation of the meeting in this way: "He looked forward to it all day. He'd kind of watch the clock and then, after school, he said, 'Should I go with [the LD teacher]?' He was so excited about it, and I guess the enthusiasm surprised me because I didn't know it would be that exciting."

As each meeting began, the special education teacher handed out the agenda and the students each began by reading introductions from their script as practiced in training. All four students demonstrated beginning levels of selfadvocacy as they took the initiative to begin their meetings with little or no prompting. The three boys introduced each person in attendance. Carrie started by welcoming everyone, introducing herself, and asking each person to introduce himself or herself.

Following introductions, each student read from his or her script. Kevin demonstrated his self-awareness and goalsetting skills as he described his present levels of performance and stated his first goal. Carrie started by explaining her first IEP goal. The DD teacher had asked to have Nathan begin by asking everyone to describe his strengths. Nic's special education teacher had asked that Nic begin by going through each section of the IEP form in the order printed. Therefore, he started by explaining the first page of his IEP.

At the end of each student's declaration, he or she asked if anyone had anything to add. At that point, other members of the IEP team offered comments regarding what the student had just shared and sometimes asked the student questions. Throughout these discussions the students experienced a sense of autonomy and self-efficacy as they responded to questions and comments and added information in meaningful ways.

In addition, each of the students deviated from their script at appropriate times throughout the meeting and engaged in essential problem-solving conversations. For example, Kevin explained, "I found out something else. When I'm working on writing fluency with print, I'm doing well. I think I need to work on cursive." The LD teacher agreed that they could work on cursive. She said they would continue to use print for spelling but would try cursive for writing words per minute. 
She noted that he should expect to backslide at first in making the transition, but they would give it a try. Kevin asked if he could work on cursive at home. His fourth-grade teacher said he would be able to take his handwriting book home.

Nathan, his father, and the general education teacher, through a problem-solving discussion that closely resembled the "Self-Determined Learning Model" described by Wehmeyer, Palmer, et al. (2000), developed a plan for him to organize his desk and locker every Friday. During his meeting, Nic read his speech goals. He said he needed to slow down and think before answering questions. This insight appeared to surprise his speech teacher. She explained the speech skills they were working on, and Nic, demonstrating self-evaluation, commented that he was good at finding words that have opposite meanings, but that finding words that mean the same thing was hard.

Nathan's homeroom teacher noted that at the beginning of the school year, when Nic came up to speak to her, he mumbled and she couldn't understand him. She told him that whenever he mumbled, she would say she couldn't hear him and walk away. She said he had gotten much better. The speech teacher stated, "Some of that has to do with confidence." Then she looked at Nic and added, "After this, you should have no trouble with confidence!"

In these descriptions of elementary students leading their IEP meetings, we have described self-advocacy skills in action. Student participation provided authentic opportunities for the students to exercise their self-advocacy skills. All four of the students answered questions and added information appropriately throughout their meetings. Furthermore, the communication during student-led meetings involved more balanced participation from the team members than the dominance of special educators at traditional meetings.

\section{Challenges Faced and Lessons Learned}

As noted in the literature, challenges involved in supporting the development of students' self-advocacy skills include:

- systemic barriers such as traditions and beliefs about adult versus student roles and responsibilities in learning,

- understanding components and significance of selfadvocacy, and

- knowledge and skill related to curricula and strategies for promoting self-advocacy.

The cases described here underscore these challenges but also highlight possibilities for bridging the research to practice gap.

\section{Systemic Barriers: Roles and Responsibilities}

In the setting where this intervention took place, the IEP was viewed as a legal document and the special education teacher was traditionally responsible for collecting information and filling out the IEP forms. The special educators shared information with the parents and general education teachers, but the student was not directly involved in the process. These practices were consistent with findings from the literature (Blue-Banning, Turnbull, \& Pereira, 2000; Vaughn, Bos, Harrell, \& Lasky, 1988).

Before the training, all the adults who were interviewed indicated that the special education teachers had the primary responsibility for setting up the IEP meeting, collecting information for the contents of the IEP, and writing the document. Figure 2 provides a pictorial representation of this process.

As the persons central to the traditional IEP process, the special educators focused on legal aspects of the IEP document. In response to questions about a typical IEP meeting, the special educators commented on paperwork requirements and soliciting information from general education teachers and parents. The EBD teacher noted that parents "really don't care to give any input. They just don't feel qualified." The LD teacher explained, "If a parent wants anything changed, we would make any kind of adjustments they think would be necessary." She added, "More often than not, they're in agreement with everything."

The general education teachers trusted the expertise of the special education teachers, were comfortable with this, and actually preferred to let them take the lead in that responsibility. Before the training, Kevin's teacher described a typical IEP meeting this way:

We get in, the special ed teacher begins, asks for a couple of little bits of input from us [general educators] and then usually they [special educators] do most of the talking. They ask, "What do you see, or what do you want to say about it?" and then they take it from there. We have just a little bit of talking we actually do at the meeting. Mostly, they take care of it.

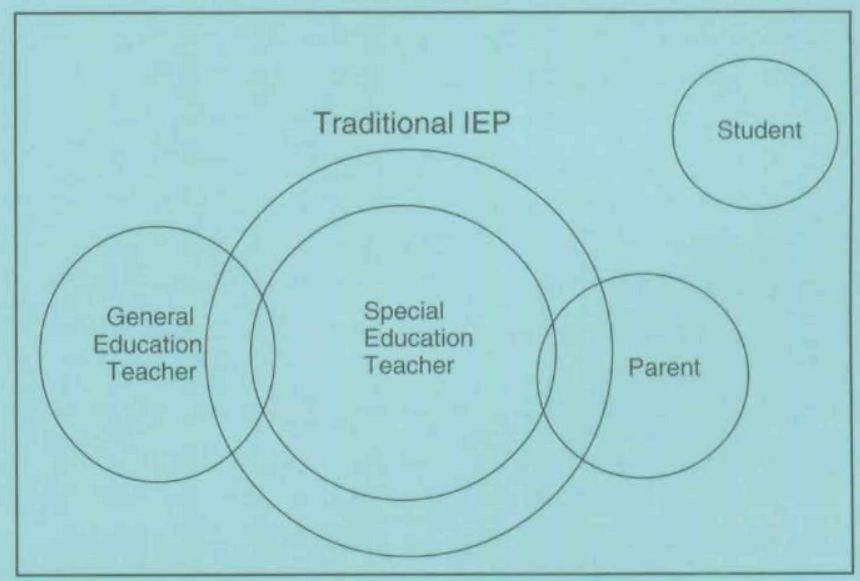

FIGURE 2

The IEP is seen as a legal document for which the special educator is largely responsible 
Nathan's teacher explained, "It's always good to go through the process of having things in writing as a reminder of what we are working on and what we are going to check later. It's more helpful to the special ed teacher than it is to the classroom teacher."

Carrie's teacher expressed a similar belief: "I think the IEP is mainly for special ed, what areas to work on, but it's good for me to know that, because then I can really target that, too."

Although the parents indicated that they felt respected as members of the IEP team, their role on the team was mainly that of listener. For example, parents perceived the IEP meeting as an opportunity to come together with the special education teacher to hear about their child's progress rather than to share information as equal partners.

Nic's stepmother's description of the IEP meeting was similar to what other parents related. In her words, the purpose of the meeting was to hear from teachers "overall how he's progressing and what he needs help with, what his strengths are, if he still needs to be getting help, or if he doesn't need to be getting help in this area."

Finally, the students were not directly part of the IEP process at this elementary school. Teachers and parents thought the main purpose of the IEP was to meet legal responsibilities of the school district. In the interviews with all adult participants, the discussions related to control of the IEP process by the special education teachers. Consequently, there was no need to have the elementary student involved in the IEP meeting. Furthermore, no one suggested that student involvement would be beneficial for the student or that student participation could enhance the IEP process.

\section{Components and Significance of Self-Advocacy}

Throughout this training there seemed to be a lack of awareness that self-advocacy skills should be promoted and taught to elementary students. The parents and teachers commented that they wanted the students to be more independent and responsible and to take more initiative and ownership for their education; but this was presented as an expectation of the students with no indication that adult intervention would be required-beyond nagging.

Prior to the request to participate in this experience, the parents and teachers had not considered the IEP meeting as an opportunity for elementary students to take that initiative or ownership. Indeed, most of the adults expected the students to be observers at these meetings and commented that it would be good for the students to hear the same information from parents and teachers at one time.

Carrie's foster mother said, "She'll see teamwork, so that's really good." Carrie's teacher explained, "I think that's actually a very good thing [student participation] because then they can hear what's going on. They can see the team- work.... It also lets them know that we're working to help them out and they shouldn't feel bad about it."

Nic's stepmother commented, "Maybe if he hears it from enough people, it will sink in." Although students did observe and listen, each was actively engaged in directing the discussion and giving meaningful input at his or her meeting.

Along with not recognizing the potential contributions of students, several parents and teachers expressed concerns about the students participating in the meeting. One of the greatest challenges in examining the participation of elementary students in the IEP process was to find teachers who were willing to participate themselves, not because of the time involved but because they did not believe that elementary students could handle the information from an IEP meeting.

One teacher said, "Fifth graders are just children. They can't do this. I don't want them to know how little progress they're making."

When asked what he thought about Nic being involved in the IEP meeting Nic's dad said, "It's good for him to be there to get everybody's input and all that, but there's things I'd like to talk about without him there, too." He was concerned about inconsistencies in Nic's performance about which Nic was sensitive. He explained that when he tried to talk to Nic about it, "He thinks I'm calling him stupid. I don't want that." Nic's teacher was concerned about Nic's difficulties with speech, noting his tendency to mumble or stutter. She said, "When he's asked to comment on something, he may not know what to say."

Nathan's parents were concerned that he might get upset with some of the suggestions that might be made at the meeting. His father stated, "It could be upsetting more than anything just because he might think he's trying as hard as he can in an area that she's pointing out, and I'd hate to see him put his brakes on altogether." Nathan's mother added, "He's done that to us before."

In these student-led IEP meetings the students exercised self-advocacy skills of self-knowledge, self-evaluation, goal setting, and problem solving as they read information from their scripts and responded to the comments and questions of other team members. As equal partners on the IEP team, parents shared their insights and concerns regarding their children. The general educators explained their expectations of the students related to classroom routines and curriculum. Accommodations were discussed with student input, and concrete plans for accomplishing goals were laid out. The special education teacher addressed all mandated elements of the IEP.

Including elementary students in their IEP meetings affected the dynamics of the group process in many positive ways without interfering with legal compliance issues. This dynamic is illustrated in Figure 3. 
Parents' and teachers' perceptions of students' ability to make meaningful contributions to the IEP meeting clearly were altered after they participated in a student-led meeting. After experiencing an elementary student-led IEP meeting, the parents, teachers, and students began to see the value in student participation. All the adult participants offered positive comments about including the elementary students in IEP meetings.

Nathan's mother exclaimed, "Actually, I thought it was one of the best meetings we've had in six years because we had what he thought were his strengths and weaknesses and we built on that."

This statement from Nic's classroom teacher echoed others:

\begin{abstract}
The focus was better. It was child-centered.... It seemed that it moved along a little faster than it usually does because we were answering his questions rather than just chitchatting. Everybody stayed on task a lot more.... I was amazed that he did it so well. Usually he stutters a lot, but he had a lot of confidence,
\end{abstract}

Regarding Kevin's participation, his LD teacher commented, "I think Kevin did a real nice job with his script and kind of facilitating the meeting and keeping things going. I was impressed with it."

Nathan's special education teacher used the word "fun" to describe the meeting:

I thought it was great! It was fun. It was very positive for Nathan. It gave him an opportunity to be a leader in a very challenging way.... I think it forced us to say things in a more positive way than if he wasn't there.... It's more fun to have the child included because I think it becomes more real to everybody.

Although the responsibility of covering mandated information, obtaining signatures, and filing the forms inevitably remained with the special education teacher, student ownership of the IEP changed markedly.

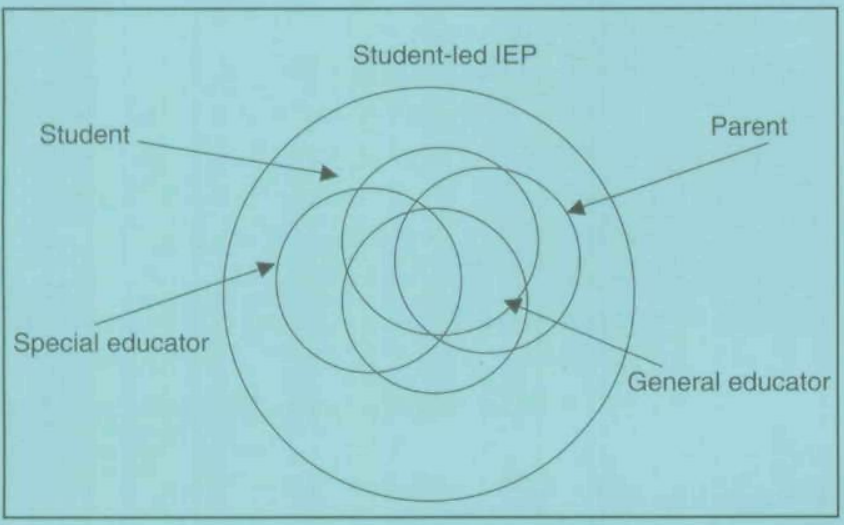

FIGURE 3

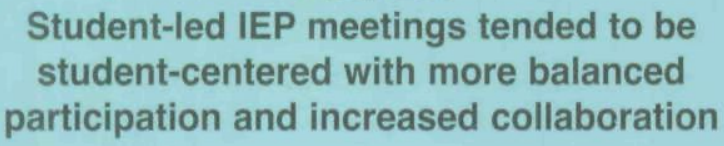

Through these experiences, the students all increased their self-confidence, which influenced their ability to selfadvocate. Carrie's social worker commented: "The response from Carrie was wonderful. I happened to see her the other day and her confidence level is way up."

Nathan's special education teacher explained, "I think the whole process made it so he took more control over his life.... He's talking about his feelings, which he'd never done before."

The components of self-advocacy and significance of students having opportunities to practice those skills were clearly demonstrated throughout this experience. Yet, the teachers expressed concerns regarding finding the time and resources to prepare students to participate.

\section{Curricula and Strategies for Promoting Self-Advocacy}

A frequently identified problem in promoting self-advocacy skills in students with disabilities is a deficit in teacher training and teachers' knowledge of curricula and strategies (Karvonen et al., 2004). Two of the special education teachers involved in this training believed they lacked the time and resources to teach students to participate actively in their IEP meetings. The LD teacher said, "I don't know how I would have the time.... I don't know if I'd want to take their instruction time away to ... teach them how to do all of that." The EBD teacher stated, "It's hard to prepare students to do this."

Neither of those teachers had a set procedure for teaching their students about the IEP, but both said that they did spend some time talking informally with their students about their IEP goals when they were collecting assessment data during instruction in the resource room. The EBD teacher explained that she talked to her students about their IEP whenever she was preparing for their meeting: "Generally, I have them do some sort of planning as I'm writing stuff up, but they generally don't choose to show up." The DD teacher stated that she had not discussed the IEP previously with any of her students.

Contrary to the beliefs of these special education teachers that the training would take a lot of time or require special materials, the training was fairly brief and the materials consisted of simple worksheets. Each of the six training sessions lasted 20 minutes or less. The sessions were spread out over 1 to 5 weeks to fit students' schedules. The materials used were the students' current IEP and simple worksheets based on concepts utilized in the Self-Directed IEP curriculum (McGahee-Kovac, 1995) and a pilot curriculum being created by the Florida State Department of Education (Cooper, Roder, Wichmanowski, \& Yeretzian, 2004). Each session consisted of an informal discussion of one or more topics related to the IEP and the students' interests, strengths, needs, and goals.

In the initial interviews the students did not know what an IEP was, and they were not able to identify their goals even 
though special education teachers of three of the students said they discussed students' goals with them. In follow-up interviews a few days after their IEP meetings, the students said they felt good about their participation. In interviews conducted 3 months later, the students expressed strong sentiments regarding their ownership of the IEP and their right to participate. As Carrie said, "I think I should know about my problem and my goals. It's my IEP meeting, and I shouldn't be left out. They're talking about me."

These case studies demonstrated that elementary students could be supported in exercising self-advocacy skills with a minimal investment of time and resources. It provided a simple plan for training students to participate meaningfully in their IEP meeting as one step that elementary teachers can take to empower their students. The knowledge, skills, and dispositions of teachers and parents played a major role in promoting student acquisition of these skills. Recognizing the barriers that students face and knowing that there are ways to remove those barriers allows us to bridge the gap between research and practice.

\section{REFERENCES}

Abery, B. (1995). Evaluating a multicomponent program for enhancing the self-determination of youth with disabilities. Intervention in School and Clinic, 30(3), 70-180.

Abery, B., \& Stancliffe, R. (1994). The ecology of self-determination. In D. J. Sands, \& M. L. Wehmeyer (Eds.), Self-determination across the life span: Independence and choice for people with disabilities (pp. 111-145). Baltimore: Brookes.

Agran, M., Blanchard, C., \& Wehmeyer, M.L. (2000). Promoting transition goals and self-determination through student self-directed learning: The self-determined learning model of instruction. Education and Training in Mental Retardation and Developmental Disabilities, 35(4), 351-364.

Agran, M. \& Hughes, C. (2005). Introduction to special issue: Self-determination reexamined are people with severe disabilities any more selfdetermined? Introduction to the special issue on self-determination: How far have we come? Research and Practice for persons with severe disabilities, 30, 105-107.

Agran, M., Snow, K., \& Swaner, J. (1999). Teacher perceptions of self-determination: Benefits, characteristics, strategies. Education and Training in Mental Retardation and Developmental Disabilities, 34(3), 293-301.

Alberto, P.A., \& Troutman, A.C. (2006). Applied behavior analysis for teachers (7th ed.). Upper Saddle River, NJ: Merrill/Prentice Hall.

Algozzine, B., Browder, D., Karvonen, M., Test, D.W., \& Wood, W.M (2001). Effects of interventions to promote self-determination for individuals with disabilities. Review of Educational Research, 71, 219-277.

Blue-Banning, M.J., Turnbull, A.P., \& Pereira, L. (2000). Group action planning as a support strategy for Hispanic families: Parent and professional perspectives. Mental Retardation, 38, 262-275.

Blum, H.T., Lipsett, L.R., \& Yocom, D.J. (2002). Literature circles: A tool for self-determination in one middle school inclusive classroom. Remedial and Special Education, 23(2), 99-108.

Borders, S., \& Paisley, P.O. (1992). Children's literature as a resource for classroom guidance. Elementary School Guidance and Counseling, 27, 131-139.

Cartledge, G., \& Kiarie, M.W. (2001). Learning social skills through literature for children and adolescents. Teaching Exceptional Children. 34(2), 40-47.

Conderman, G., \& Katsiyannis, A. (2002). Instructional issues and practices in secondary special education. Remedial and Special Education, 23(3), 169-179.
Cooper, E., Roder, F., Wichmanowski, D., \& Yeretzian, S. (2004). Standing up for me: Strategies for teaching self-determination skills. Tallahassee, FL: Florida Department of Education.

Cross, T., Cooke, N.L., Wood, W.M., \& Test, D.W. (1999). Comparison of the effects of MAPS and ChoiceMaker on student self-determination skills. Education and Training in Mental Retardation and Developmental Disabilities, 34, 499-510.

Deci, E.L., \& Ryan, R.M. (1985). Intrinsic motivation and self-determination in human behavior. New York: Plenum Press.

Deci, E. L., \& Ryan, R. M. (2000). The "what" and "why" of goal pursuits: Human needs and the self-determination of behavior. Psychological Inquiry, 11, 227-268.

DiAdamo, C. (2005). An errorless approach to management of child noncompliance in a special education setting. School Psychology Review, 34(1), 107-115.

Doll, B., Sands, D. J., Wehmeyer, M. L., \& Palmer, S. (1994). Promoting the development and acquisition of self-determined behavior. In D. J. Sands, \& M. L. Wehmeyer (Eds.), Self-determination across the life span: Independence and choice for people with disabilities (pp. 65-90). Baltimore: Brookes.

Eckes, S.E., \& Ochoa, T.A. (2005). Students with disabilities: Transitioning from high school to higher education. American Secondary Education, 33(3), 6-20.

Eisenman, L., Chamberlin, M., \& McGahee-Kovac, M. (2005). A teacher inquiry group on student-led IEPs: Starting small to make a difference. Teacher Education and Special Education, 28(3-4), 195-206.

Fiedler, C.R., \& Clark. D. (2008). Making a difference: Advocacy competencies for special education professionals (2nd ed.). Austin, TX: Pro-Ed.

Field, S. (1996). Self-determination instructional strategies for youth with learning disabilities. Journal of Learning Disabilities, 29, 40-51.

Field, S. \& Hoffman, A. (2002). Preparing youth to exercise self-determination: Quality indicators of school environments that promote the acquisition of knowledge, skills and beliefs related to self-determination. Journal of Disability Policy Studies, 13, 113-118.

Field, S., Martin, J., Miller, R., Ward, M., \& Wehmeyer, M. (1988) Selfdetermination for persons with disabilities: A position statement of the Division on Career Development and Transition. Career Development for Exceptional Individuals, 21, 113-127.

Ford, D.Y. (2000). Multicultural literature and gifted black students: Promoting self-understanding, awareness, and pride. Roeper Review, 22 , $235-240$.

Grover, S. (2005). Advocacy by children as a causal factor in promoting resilience. Childhood, 12(4), 527-538.

Halpern, A.S., Herr, C.M., Wolf, N.K., Lawson, J.D., Doren, B., \& Johnson, M.D. (1997). NEXT S.T.E.P.: Student transition and educational planning. Austin, TX: Pro-Ed.

Hammer, M.R. (2004). Using the self-advocacy strategy to increase student participation in IEP conferences. Intervention in School and Clinic, 39(5), 295-300.

Harris, V.J. (1991). Multicultural curriculum: African American children's literature, Young Children, 46(2), 37-44

Individuals with Disabilities Education Act, 20 U.S.C. Sec. 1401 et seq.

Izzo, M.V., Hertzfeld, J.E., \& Aaron, J.H. (2001). Raising the bar: Student self-determination + good teaching $=$ success. Journal of Vocational Special Needs Education, 24(1), 26-36.

Karvonen, M., Test, D.W., Wood, W.M., Browder, D., \& Algozzine, B (2004). Putting self-determination into practice, Exceptional Children, $7 I(1), 23-41$.

Katsiyannis, A., Zhang, D., Woodruff, N., \& Dixon, A. (2005). Transition supports to students with mental retardation: An examination of data from the National Longitudinal Transition Study 2. Education and Training in Developmental Disabilities, 40(2), 109-116.

Keyes, M.W., \& Owens-Johnson, L. (2003). Developing person-centered IEPs. Intervention in School and Clinic, 38, 145-152.

Konrad, M., Helf, S., \& Itoi, M. (2007). More bang for the book: Using children's literature to promote self-determination and literacy skills. Teaching Exceptional Children, 40(1), 64-71.

Lancaster, P.E., Schumaker, J.B., \& Deshler, D.D. (2002). The development and validation of an interactive hypermedia program for teaching a 


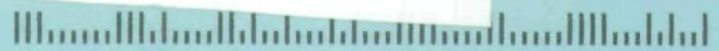

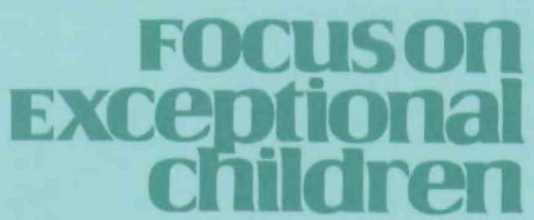

self-advocacy strategy to students with disabilities. Learning Disability Quarterly, 25, 277-302.

Malian, I., \& Nevin, A. (2002). A review of self-determination literature: Implications for practitioners. Remedial and Special Education, 23(2), $68-74$.

Martin, J.E., \& Marshall, L.H. (1995). ChoiceMaker: A comprehensive self-determination transition program. Intervention in School and Clinic, 30, 147-156.

Martin, J.E., Marshall, L.H., Maxson, L., \& Jerman, P. (1993). Self-directed IEPs: Teacher's manual. Colorado Springs: University of Colorado, Center for Educational Research.

Mason, C.Y., McGahee-Kovac, M., \& Johnson, L. (2004). How to help students lead their IEP meetings. Teaching Exceptional Children, 36(3). $18-24$.

McGahee-Kovac, M. (1995). A student's guide to the IEP. Washington, DC: NICHCY.

Merchant, D.J.. \& Gajar, A. (1997). A review of the literature on self advocacy components in transition programs for students with learning disabilities. Journal of Vocational Rehabilitation, 8, 223-231.

Miller, A.B., \& Keys, C.B. (1996). Awareness, action, and collaboration: How the self-advocacy movement is empowering for persons with developmental disabilities. Mental Retardation, 34(5), 312-319.

Mithaug, D.E. (1996). Equal opportunity theory. Thousand Oaks. CA: Sage.

Nelson, S.W., McGhee, M.W., Meno, L.R., \& Slater, C.L. (2007). Fulfilling the promise of educational accountability. Phi Delta Kappan, $88(9), 702-709$.

No Child Left Behind Act of 2001, 20 U.S.C. 6301 et seq.

Perner, D. E. (2007). No child left behind: Issues of assessing students with the most significant cognitive disabilities. Education and Training in Developmental Disabilities, 42(3), 243-251.

Powers, L.E. (1996). TAKE CHARGE transition planning project. (Grant No. HH158U50001 from U.S. Department of Education and Oregon Health Sciences). Portland: Oregon Health Sciences University.

Price, L.A., Wolensky, D., \& Mulligan. R. (2002). Self-determination in action in the classroom. Remedial and Special Education, 23(2), 109-115.

Reeve, J. (2006). Teachers as facilitators: What autonomy-supportive teachers do and why their students benefit. Elementary School Journal, 106. 205-236.

Sands, D. J., Bassett, D. S., Lehmann, J., \& Spencer, K. C. (1998). Factors contributing to and implications for student involvement in transition-related planning decision making and instruction. In M. L. Wehmeyer \& D. J. Sands (Eds.), Making it happen: Student involvement in education planning, decision making, and instruction (pp. 25-44). Baltimore: Brookes.

Sands, D.J., \& Doll, B. (1996). Fostering self-determination is a developmental task. Journal of Special Education, 30, 58-76.

Schreiner, M.B. (2007). Effective self-advocacy: What students and special educators need to know. Intervention in School and Clinic, 42, 300-304.

Seligman, M. E. P. (1975). Helplessness: on depression, development, and death. San Francisco: W. H. Freeman.

Snyder. E.P., \& Shapiro, E.S. (1997). Teaching students with emotional/ behavioral disorders the skills to participate in the development of their own IEPs. Behavioral Disorders, 22(4), 246-259.

Sorrentino, A., \& Zirkel, P.A. (2004). Is NCLB leaving special education students behind? Principal, 83(5), 26-29.

Sridhar, D., \& Vaughn, S. (2000). Bibliotherapy for all: Enhancing reading comprehension, self-concept, and behavior. Teaching Exceptional Children, 33(2), 74-82.

Sutherland, K. S. \& Singh, N. N. (2004). Learned helplessness and students with emotional behavioral disorders: Deprivation in the classroom. Behavioral Disorders, 29, 169-181.

Test, D.W., Browder, D.M., Karvonen, M., Wood, W., \& Algozzine, B. (2002). Writing lesson plans for promoting self-determination. Teaching Exceptional Children, 35(1), 8-14.

Test, D.W., Fowler, C.H., Wood, W.M., Brewer, D.M., \& Eddy, S. (2005). A conceptual framework of self-advocacy for students with disabilities. Remedial and Special Education, 26(1), 43-54.

Test, D.W., Karvonen, M.. Wood. W.M., Browder, D., \& Algozzine, B. (2000). Choosing a self-determination curriculum. Teaching Exceptional Children, 33(2), 48-54.
Test, D.W., Mason, C., Hughes, C., Konrad, M., Neale, M., \& Wood, W.M. (2004). Student involvement in individualized education program meetings. Exceptional Children, 70(4), 391-412.

Test, D.W., \& Neale, M. (2004). Using the self-advocacy strategy to increase middle graders' IEP participation. Journal of Behavioral Education, 13(2), 135-145.

Torgerson. C.W., Miner, C.A. \& Shen. H. (2004). Developing student competence in self-directed IEPs. Intervention in School and Clinic, 39(3), $162-167$.

Traustadottir, R. (2006). Learning about self-advocacy from life history: A case study from the United States. British Journal of Learning Disabilities, 34(3), 175-180.

Turnbull, A., Turnbull, R., Erwin, E., \& Soodak, L. (2006). Families, professionals, and exceptionality: Positive outcomes through partnership and trust (5th ed.). Upper Saddle River, NJ: Merrill/Prentice Hall.

Van Reusen, A.K., \& Bos, C.S. (1994). Facilitating student participation in individualized education programs through motivation strategy instruction. Exceptional Children, 22(4), 466-475.

Van Reusen, A.K., Bos, C.S., Schumaker, J.B., \& Deshler, D.D. (1994). The self-advocacy strategy for education and transition planning. Lawrence, KS: Edge Enterprises.

Vaughn, S., Bos, C. S., Harrell, J. E., \& Lasky, B. A. (1988). Parent participation in the initial placement IEP conference ten years after mandated involvement. Journal of Learning Disabilities, 21, 82-89.

Wagner, M., Kutash, K., Duchnowski, A.J.. \& Epstein, M.H. (2005). The special education elementary longitudinal study and the national longitudinal transition study: Study designs and implications for children and youth with emotional disturbance. Journal of Emotional and Behavioral Disorders, 13(1), 25-41.

Wagner, M., Kutash, K., Duchnowski, A.J., Epstein, M.H., \& Sumi, W.C. (2005). The children and youth we serve: A national picture of the characteristics of students with emotional disturbances receiving special education. Journal of Emotional and Behavioral Disorders, 13(2), 79-96.

Walker, R., \& Bunsen, T. D. (1995). After high school: The status of youth with emotional and behavioral disorders. Career Development for Exceptional Individuals, 18, 97-107.

Ward, M. J. (1994). Coming of age in the age of self-determination: A historical and personal perspective. In D.J. Sands \& M. L. Wehmeyer (Eds.), Self-determination across the life span: Independence and choice for people with disabilities (pp. 1-16). Baltimore: Brookes.

Wehmeyer, M.L., Agran, M., \& Hughes, C. (1998). Teaching self-determination to students with disabilities: Basic skills for successful transition. Baltimore: Paul H. Brookes.

Wehmeyer, M.L., Agran, M., \& Hughes, C. (2000). A national survey of teachers' promotion of self-determination and student-directed learning. Journal of Special Education, 34, 58-68.

Wehmeyer, M.L.. \& Lawrence, M. (1995). Whose future is it anyway? Promoting student involvement in transition planning. Career Development for Exceptional Individuals, 18(20), 69-83.

Wehmeyer, M.L., Palmer, S.B., Agran, M., Mithaug, D.E., \& Martin, J.E. (2000). Promoting causal agency: The self-determined model of instruction. Exceptional Children, 66(4), 439-453.

Wehmeyer, M.L., \& Schalock, R.L. (2001). Self-determination and quality of life: Implications for special education services and supports. Focus on Exceptional Children, 33(8), 1-13.

Wehmeyer, M.L., \& Schwartz, M. (1997). Self-determination and positive adult outcomes: A follow-up study of youth with mental retardation or learning disabilities. Exceptional Children, 63, 245-255.

Wehmeyer, M.L., \& Schwartz, M. (1998). The relationship between selfdetermination and quality of life for adults with mental retardation. Education and Training in Mental Retardation and Developmental Disabilities, 33, 3-12.

Wolfensberger, W.. \& Nirje, B.. (1972). The principle of normalization in human services. Toronto, Ontario, Canada: National Institute on Mental Retardation.

Zhang, D. (2001). The effect of Next S.T.E.P. instruction on the self-determination skills of high school students with learning disabilities. Career Development for Exceptional Individuals, 24(2), 121-132. 
Copyright of Focus on Exceptional Children is the property of Love Publishing Company and its content may not be copied or emailed to multiple sites or posted to a listserv without the copyright holder's express written permission. However, users may print, download, or email articles for individual use. 